\title{
Dendê: com a África à boca
}

\section{Palm oil: with Africa to the mouth}

\author{
Raul Lody - Doutor em Antropologia. Museu de Gastronomia Bahiana Senac BA, Brasil - \\ axe.luar@gmail.com
}

Palavras-chave:

Patrimônio cultural

gastronômico.

Religiosidade.

Identidade Cultural.
Keywords:

Gastronomic cultural heritage. Religiosity. Cultural Identity.

\section{RESUMO}

Este artigo fundamenta-se nas pesquisas de campo que realizei no Brasil e em países africanos. As pesquisas formam uma base etnográfica reveladora das muitas relações entre o continente africano e o Brasil, e com isso a criação de acervos patrimoniais únicos que atestam a nossa pluralidade cultural. Este artigo quer mostrar, através de relatos históricos, etnografias comparadas, e pesquisas de campo, como o azeite de dendê se tornou uma marca da identidade de matriz africana no Brasil. Como o dendezeiro saiu da África e chegou ao Brasil. Também apontar como, a partir dos seus significados na economia, na religiosidade e na gastronomia, passou a marcar uma comida de matriz africana que representa a identidade de um ofício artesanal que foi patrimonializado pelo Instituto do Patrimônio Histórico e Artístico Nacional (IPHAN). Ainda, como os terreiros de Candomblé se tornaram um importante guardião dos saberes e dos fazeres de matriz africana no Brasil. E, a baiana de acarajé com seu ofício e com sua "roupa de baiana" tradicional, passou a ser um símbolo que representa um importante passo na preservação da cultura de matriz africana no Brasil.

\section{ABSTRACT}

This article is based on the field research that I carried out in Brazil and in African countries. The research forms an ethnographic basis revealing the many relations between the African continent and Brazil, and with it the creation of unique heritage collections that attest our cultural plurality. This article aims to show, through historical reports, comparative ethnographies, and field research, how palm oil has become a hallmark of the African matrix identity in Brazil. As the palm tree left Africa and arrived in Brazil. Also to point out how, from its meanings in economy, religiosity and gastronomy, started to mark a food of African matrix that represents the identity of an artisan craft that was recognized heritage by brazilian National Historic and Artistic Heritage Institute (IPHAN). Also, as the Candomblé's places of practice (a.k.a. terreiros) became an important guardian of the knowledge and makings of African matrix in Brazil. And, Bahia's women of acarajé with its craft and with its traditional "Bahia's clothing", became a symbol that represents an important step in the preservation of the African matrix culture in Brazil.

Como citar este artigo

LODY, Raul, Dendê: com a África à boca. Revista Brasileira de Gastronomia, Florianópolis, v. 1, n. 1, p. 1833, jul./dez. 2018. Disponível em: http://rbg.sc.senac.br/index.php/gastronomia/article/view/31. Acesso em: $d d m m$ aa. 


\section{INTRODUÇÃO}

\subsection{0 que chega da Costa}

Gilberto Freyre diz que o brasileiro é bi-africano. Primeiramente porque ele é africano pela presença da civilização Magrebe na península Ibérica, sendo também civilizadora do nosso colonizador lusitano, homem que traz ainda com ele as influências dos muitos contatos comerciais que ele manteve com o continente africano em suas Costas, ocidental, oriental e austral, durante o tráfico de africanos em condição escrava. E segundo, por causa da quantidade de escravos que cocivilizaram o Brasil com a sua chegada, mesmo que em condição escrava.

E assim, todos estes encontros interafricanos e transafricanos com Portugal fazem com que ocorra uma colonização também africana no Brasil.

A colonização oficial portuguesa é multicultural, e traz memórias fundadoras do homem luso, que reconhecem nele os povos afro-islâmicos, civilização Magrebe, de onde chegam as técnicas de navegação, avançadas para a época, que possibilitaram Portugal viajar por mares nunca d'antes navegados.

E a partir das Grandes Navegações, ampliou-se os processos de expansão de territórios, de novos mercados, de especiarias, que se unem ao estilo colonial da fixação de Portugal no Brasil a partir do cana-de-açúcar.

Portugal já experimentava a agricultura da cana-de-açúcar no Algarve, nas ilhas Atlânticas e, em especial, na Madeira; onde se consolida as formas de moagem da cana nos engenhos para a fabricação do melado e do açúcar. E assim estas tecnologias passam a orientar e manter o açúcar nos engenhos no Brasil.

Para se plantar a cana-de-açúcar, e fazer açúcar no Brasil, chega o braço africano, numa nova e intensa re-africanização que ocorreu por mais de três séculos, e que se estendeu até o século XIX.

Isso determinou a maior imigração da história por meio do tráfico de africanos em condição escrava, numa cifra estimada entre 4 a 6 milhões de pessoas. Chegavam também para encontrar ouro, plantar café, cozinhar, vender comida nas ruas - os ganhos -, entre muitos outros ofícios artesanais.

O açúcar proveniente da cana sacarina - Saccharum officiarum L. - vem para criar e determinar sistemas alimentares, e se torna uma verdadeira revolução de sabores no mundo. 0 açúcar se une às receitas medievais dos conventos de Portugal, que junto a doçaria Magrebe, traz muitas receitas que tomam a forma e o gosto brasileiro, entre elas o nosso arroz doce - roz bil alib.

Nestes cenários de grandes acervos culinários, inclui-se uma doçaria com as frutas tropicais, frutas "da Terra": pitanga, goiaba, araçá, caju, entre muitas outras. E, uma feita com as frutas exóticas, orientais, "do Reino", como jaca, manga, fruta-pão, coco - Cocos nucifera -; que foram abrasileiradas, e se integraram as nossas memórias e as nossas referências de paladar.

O coco, já chamado de coco da Índia, tornou-se a base culinária para muitas receitas doces e salgadas. Inclusive no arroz doce que substituiu originalmente o leite de amêndoas e passou a ser enriquecido com leite de coco, misturado às especiarias cravo e canela.

E tantos outros pratos tradicionais feitos com coco que se tornaram tradicionais de lá para cá, especialmente no Nordeste: feijão de coco; peixe de coco; camarão de coco. Também, emblemática é a cocada feita de coco ralado e açúcar,

Ainda, ingredientes sul-americanos como o milho, com uma biodiversidade que possui centenas de tipos, e no seu uso milenar há mais de 7000 anos nas receitas dos Incas, vai conformar 
a nossa identidade alimentar brasileira. E até hoje, mingaus, pamonha - tamal -, estão nas mesas do cotidiano e nas mesas das festas dos brasileiros.

Nesse cenário, já multicultural, a comida afrodescendente no Brasil marca e determina imaginários e técnicas culinárias com o uso do dendê. A palmeira do dendezeiro - Elaeis guineenses L. -, que é um grande símbolo da África, passa a fazer parte do nosso imaginário, como a oliva faz parte do imaginário ibérico.

E com o dendê, chega da África o inhame (gênero Dioscorea Colocasia), o quiabo (Hibiscus esculentos), e outros produtos "da Costa" como, por exemplo, os panos da Costa; os búzios da Costa; a palha da Costa, entre tantos outros que tiveram essa denominação.

O dendezeiro é uma palmeira que produz cachos generosos, tendo por média de duzentos cocos por cacho. O principal produto extraído da polpa dos cocos é o azeite. Desta palmeira tudo é aproveitado, a madeira para construção de casas, as fibras para a sua cobertura. E por isso é chamada na África de a árvore do paraíso.

No Brasil, o azeite de dendê criou novos sabores, e dá aos pratos uma estética peculiar, que traz uma nova identidade à mesa. É o caso da farofa, que é uma realização genuinamente brasileira. A farinha de mandioca mistura-se tanto com o dendê quanto com o mel de engenho da cana de açúcar, para alimentar a todos nos engenhos, que sempre tiveram ao lado uma casa de farinha para alimentar senhores e escravos.

Farinha crua ou cozida, misturado com diferentes ingredientes alimentou e continua a alimentar milhares de brasileiros em diferentes partes do Brasil, sendo ingrediente principal ou acompanhamento para diferentes receitas.

Atualmente, a farofa amarela ou farofa vermelha, feita com azeite de dendê, passa a acompanhar outras receitas também feitas com azeite de dendê como, por exemplo, xinxim de galinha - galinha temperada com dendê, camarão seco, cebola e gengibre -; efó - feito com folha de mostarda, peixe, camarão seco e dendê -; moquecas - tipo de guisado de peixes, crustáceos, ovos, carne bovina, vísceras misturada com tomate, cebola, pimentões, pimenta e leite de coco.

Porém o azeite de dendê ganha verdadeiramente a sua sacralidade na fritura do acarajé bolinho feito de feijão fradinho, cebola e sal. É uma comida ritual dos terreiros de matriz africana, sendo chamado de "bolo de fogo". Comida do orixá lansã - divindade loruba que representa o vento e o fogo. $O$ acarajé tornou-se um dos mais notáveis símbolos da cozinha africana no Brasil. Ainda, com a massa do acarajé, acrescida com camarões secos moídos, gengibre e azeite de dendê, faz-se o abará, que é embalado na folha de bananeira para ser cozido.

O quiabo é outra base alimentar vinda 'da Costa' que se mistura com o dendê, e que está no cotidiano das nossas mesas. Assim, a quiabada, feita com quiabos cozidos e carne bovina fresca e/ou charque, pimenta e muito azeite de dendê, e acompanhada pela sempre presente farinha de mandioca. A quiabada pode ser acompanhada também com pirão ou arroz branco, mais insosso, para se harmonizar a intensidade do prato.

Outra receita feita com quiabos é o caruru, um prato ritual que é preparado tanto nas casas quanto nos terreiros de candomblé. A receita mostra um uso generoso do azeite de dendê que se integra ao sabor da castanha de caju, do amendoim, da cebola, dos camarões, frescos e secos; da carne bovina e/ou do peixe.

E com o inhame 'da Costa' é feita uma receita com ele muito cozido e azeite e de dendê chamada de "ipeté", também se pode acrescentar camarão seco. Este também é um prato ritual 
dos terreiros de matriz africana que é dedicado ao orixá Oxum - divindade loruba das águas dos rios. A receita do ipeté remete a um ancestral histórico do nosso tão querido bobó ou o bobó de camarão.

E um exemplo multicultural é a receita do "olubó", feita com o inhame da Costa cozido sem temperos, amassado e moldado na forma de bolas, para ser comido com mel de cana de açúcar, ou mesmo para acompanhar pratos condimentados com muito azeite de dendê e molho de pimenta.

Nesse cenário de sabores marcados pelo dendê, destaque para o uso das pimentas: pimentado-reino (Piper nigrum); "ataré" ou pimenta-da-costa (Amomum granum-paradisi L.). E, para as pimentas nativas, 'da Terra', do gênero Capsicum frutescens Wild: cambuci, pimenta-de-cheiro; malagueta - com mais de 150 tipos; dedo-de-moça; pimenta-biquinho; todas boas de arder e de temperar.

As pimentas frescas, secas, cozidas, refogadas; maceradas em azeite. Destaque para o molho Nagô que é feito à base de pimentas secas e frescas que são frigidas no azeite de dendê, usada para acompanhar o acarajé e o abará. Sem dúvida, os usos das pimentas promovem e possibilitam encontros gastronômicos com o que é 'da Terra', 'do Reino' e 'da Costa'.

Outro caso emblemático que está dentro do nosso imaginário sobre comidas africanas no Brasil com o uso do azeite de dendê é o vatapá. Um prato multicultural de criação afro-brasileira, e que traz referências das cozinhas ibéricas e das cozinhas africanas.

Já que em Lisboa, Portugal, há uma receita chamada de açorda que é feita a partir do aproveitamento do pão saloio, salsa, alho, azeite de oliva, e gemas de ovos, o que nos aproxima muito da receita do nosso celebrado vatapá, que usa azeite de dendê ao invés do azeite de oliva.

Esse prato também une o pão feito com a farinha do Reino, farinha de trigo, com o leite de coco do Oriente. São muitos os estilos de se fazer vatapá desde a época do Império, isso aqui no Brasil, como, por exemplo, vatapá feito com peixe, fresco ou seco, como o bacalhau, com porco, com galinha. Eram muitas e diferentes formas de se fazer vatapá à época.

Contudo, nestes muitos e diversos cenários sociais da comida nos seus territórios, físico e simbólico, diversos ingredientes de diferentes procedências vão se fortalecer pelo uso, e passam a construir um processo memorial coletivo dentro da alimentação.

E assim, a matriz africana está presente no só com o azeite de dendê, mas foi ele que mais verdadeiramente identifica esse patrimônio alimentar que chega da África para marcar o Brasil.

\subsection{Dendezeiro uma palmeira que tudo dá}

A palmeira do dendezeiro é originária da Costa ocidental africana, e se estende até a Costa austral. Ela é, sem dúvida, a mais importante palmeira do continente africano. Palmeira fundamental para a economia deste continente porque do dendezeiro tudo é usado, folha, tronco, frutos; ainda, o seu palmito para alimentação, da sua seiva se faz uma bebida fermentada, o vinho de dendê; além do seu produto mais consagrado que é o azeite de dendê que é extraído do seu fruto.

A planta tem inflorescências masculinas e femininas separadas, e cresce, uma ou outra, na axila das folhas. Diante de tantos significados do dendezeiro para as civilizações africanas, os portugueses passaram a olhar para esta planta também de maneia plural e complexa.

A introdução da palmeira dendém, como é chamada em Angola, ocorreu durante o tráfico de africanos em condição escrava e, em especial, nos séculos XVI e XVII. 
Em contexto brasileiro, durante muitos anos, pode-se dizer que apenas na Bahia o dendezeiro já possibilitava a feitura do óleo ou azeite de palma ou dendê. E por isso este ingrediente é notável principalmente nas receitas tradicionais da cozinha do Recôncavo baiano.

A construção do paladar, das receitas, dos temperos, das maneiras de fazer e de servir, da predominante população afrodescendente que se formou no Brasil foi organizada durante um longo processo histórico, econômico, social, cultural e simbólico.

Assim, a partir do olhar do homem lusitano para o dendê africano, e com as Grandes Navegações portuguesas, que realizaram uma ampla difusaõ de alimentos entre o Ocidente e o Oriente, nos séculos XVI, XVII e XVIII, numa verdadeira primeira grande globalização; fez com que as cozinhas regionais do Brasil fossem um retrato deste processo multicultural, que se deu pelas diferentes "Áfricas" que aqui chegaram com e os seus diferentes sistemas alimentares peculiares.

Nestes contextos, vê-se que o dendê tem um grande destaque na formação de um dos sistemas alimentares brasileiro.

O fazer azeite de dendê, segundo a tradição afrodescendente, segue tecnologias artesanais que buscam pela produção do melhor azeite, aquele que é conhecido e considerado como da flor do dendê.

\begin{abstract}
"O coco do dendezeiro tem casca mole de onde se extrai o óleo, na sequência com as mãos se realiza "bater! o dendê em etapa chamada" cafuné," para então, se separar o "bagunço", o aguchó, que é a palha residual do fruto. Agora é o processo do refinamento do óleo extraído, que se deixa dormir, para decantar, separando assim o azeite grosso, da lama do fundo. Do óleo levado ao fogo logo se forma na superfície o "catete", espuma que se separa que se retira do recipiente onde se realiza a purificação do azeite. E agora o axoxó, de cor branca amarelada, consistência de manteiga que é também um subproduto resultado deste processo de se fazer azeite. E assim finalizando este processo artesanal tem-se $\mathrm{p}$ melhor azeite que é o da flor a flor de azeite, com o dendê, na sua linda cor, odor e em especial o sabor para integrar tantas receitas." (Edison Carneiro. Ladinos e crioulos. Pg. 74)
\end{abstract}

Outra descrição sobre o processo artesanal de se fazer o azeite é a relatado por Edison Carneiro, como acontece no Recôncavo da Bahia.

\begin{abstract}
“Os rácimos separados pela foice são expostos durante quatro dias, no mínimo, ao sol e mesmo unicamente três dias, se têm frutos bem maduros. Então toma-se cerca de dois quilos de frutos e se cozinha, em marmita de ferro, e a massa polposa que deles resulta é pisada em um almofariz ou pilão e misturada com água morna. Com a mão separam-se então as fibras do envoltório dos caroços e se deitam fora umas e outras. $O$ óleo que sobre nada é misturado com água morna; deita-se o todo em uma peneira depois a polpa é posta a ferver em água até que não deixe mais exsudar novo óleo, novamente é passado em peneira e assim seguidamente até que as polpas não contenham mais óleo. $O$ óleo, assim separado em diversas vezes, é reunido e fervido até a eliminação d'água (...)." (Ibidem. Pg. 74)
\end{abstract}

No Brasil, a comida feita com dendê tem o seu primeiro grande consumo com os "ganhos" - venda ambulante de comida nas ruas -, que aconteciam em muitas capitais e, em especial, Salvador, Recife e Rio de Janeiro; além de outras cidades que tivessem grande concentração de africanos, e seus descendentes, nos séculos XVIII e XIX.

As quituteiras, quitandeiras ou negras de ganho, vendiam: pratos à base de feijões, angu de milho; bebidas, como o vinho de dendê, emu ou malafo; mingaus doces, quase líquidos. Atualmente, 
ainda há a venda ambulante de mingaus nas ruas e praças da Bahia, só que feitas também por homens.

Os hábitos alimentares, em âmbito doméstico, assumiram o papel de manter estas receitas tradicionais de rua, especialmente nos dias de festa, marcadas pelo leite de coco e pelo dendê. $E$ as comidas feitas com azeite de dendê são comumente chamadas de comidas-de-azeite.

Outro importante espaço guardião do uso do dendê e a culinária africana no Brasil, e certamente é o terreiro. Terreiro de candomblé, de Tambor Mina, de Batuque, de Xangô, entre outros, têm na cozinha sagrada, e cerimonial, um importante ponto de contato as memorias ancestrais africanas.

Muitos alimentos que são feitos nos terreiros são os mesmos que são feitos nas casas. 0 caruru, por exemplo, agora interpretado num contexto religioso, ainda que na sua base de quiabos, é um prato e ao mesmo tempo um cardápio que celebra nas festas familiares a devoção aos santos gêmeos, São Cosme e São Damião, santos que no processo da analogia sagrada passa a ser relacionada ao culto dos Ibejis, patronos das mulheres grávidas e das crianças gêmeas.

E assim este amplo e diverso culto afro-brasileiro se dá com o caruru-dos-lbejis ou carurude-Cosme, que seguem as mesmas receitas e finalidades religiosas, tanto na casa quanto no terreiro.

O caruru é também um cardápio para um banquete de celebração que é formado por vatapá, abará, o acarajé, feijão-de-azeite, acaçá, farofa de azeite, ebô, xinxim de galinha, cocada, rolete de cana, pipoca, e o caruru de quiabos propriamente dito.

\subsection{0 "igi-opé": a árvore sagrada}

Para os loruba, povo com concentração no Benin e na Nigéria, o dendezeiro é uma árvore sagrada conhecida como igi-ope, e representa o orixá Ogum, que é agricultor, caçador, artesão, e aquele que domina tecnologias.

O sentido sagrado da natureza faz uma das mais notáveis referências no entendimento das tradições de matriz africana. E assim os ingredientes têm um valor especial, e se encontram integrados diretamente aos elementos da natureza e aos Orixás, e, desta maneira, há uma compreensão para se preservar o meio ambiente porque tudo nele e sagrado.

E a natureza marca este sentido sagrado no ingrediente que aciona a divindade quando é usado nos diversos cardápios dos terreiros de candomblé, para assim realizar a comunicação entre o homem e o orixá.

As comidas ganham as mesas das casas, dos mercados, dos tabuleiros nas ruas, dos restaurantes, para marcar sempre as representações socioculturais, sejam elas, entre o cotidiano e a festa, entre o homem e a sua devoção.

Destaque para as festas que acontecem nas praças e nos adros das igrejas; festas ampliadas e populares como de Santo Antônio e São João; Carnaval; Cosme e Damião; Santa Bárbara; entre outras na Bahia; que estão sempre permeadas pelo sincretismo religioso afro-baiano.

Assim, há um forte sentimento de que o azeite de dendê está na maioria das receitas que fazem parte dos cardápios destas festas, e que são também os cardápios dos orixás.

O dendê tem uma identificação marcante com Exu, orixá essencialmente da comunicação, da sexualidade. Exu, juntamente com o dendê, encarna um amplo sentido telúrico africano. Exu passa a ser o próprio dendê, como o dendê passa a ser Exu, sem que com isto se limite no uso ou a função ritual-religiosa do dendê, tanto para o seu culto nos santuários, como nos seus alimentos. 
É uma visão fundamentalmente ética e moral reunir Exu e o dendê, como se, ao mesmo tempo, o homem africano fosse o dendê, e ainda fosse a África. Isto reforça um conceito de terra, de chão.

A diáspora do dendê está integrada à diáspora africana e, em especial, na faixa litorânea atlântica no Brasil, nos bolsões de manifestações aonde o pensamento, a ação e o testemunho reafirmam um sentido afro-brasileiro.

Exu é também dono dos dendezeiros, cuja abundância dos cachos com centenas de cocos vicejam em cada coqueiro adulto, e são resultado da ação fértil e benfazeja de Exu, que é também um orixá fitolátrico.

\subsection{A africanização da farinha de mandioca: o pirão rouge.}

Há um crescente desejo de valorização dos hábitos alimentares a partir dos ingredientes locais, 'da Terra'.

Nessa busca pela preservação da biodiversidade e pela continuidade dos diferentes processos produtivos, e das receitas que trazem representações culinárias e atestam a diversidade e as identidades culturais, vigora um sentimento dominante de terroir.

No caso brasileiro, a mandioca ganha destaque dentro da nossa biodiversidade, por ser uma raiz nativa com centenas de tipos comestíveis. E com os diferentes sabores desta raiz americana, construiu-se diferentes sistemas alimentares que há milhares de anos fazem parte da vida dos povos nativos.

A mandioca tem um sentido nacional, e a partir dos seus muitos subprodutos derivados e, em especial, as muitas farinhas que existem, é possível identificar lugares e/ou regiões do Brasil.

Além do consumo das suas folhas, a maniva, na saborosa maniçoba; também são utilizados outros produtos derivados da mandioca como: tucupi, goma, puba, massa de mandioca, entre tantos.

O brasileiro se identifica como um comedor e apreciador de farinha de mandioca, farinha seca; farinha-de-guerra; farinha-da-terra; farinha-de-mesa; farinha-de-pau; farinha-d'água;

São farinhas que trazem as suas marcas autorais desde a época dos engenhos de açúcar, seja por causa da forma com é peneirada, escaldada, ou torrada artesanalmente, momento em que se revela o estilo autoral da "casa de farinha".

Ainda, algumas farinhas são temperadas durante o seu processo de produção com o tucupi.

As farinhas estão integradas às refeições, e especialmente como complementação do clássico feijão com farinha; além de muitos outros pratos que só estarão completos quando acrescidos de farinha de mandioca.

Destaque para o seu uso no preparo de pirões e farofas, que são exemplos de realizações telúricas, verdadeiramente nativas.

As invenções gastronômicas que surgem a partir da mandioca determinam uma verdadeira marca do nosso hábito alimentar, e com dimensão nacional; e assim é possível manter as referências desta nossa memória de paladar.

E está no pirão um tema quase épico da obra de Gilberto Freyre. O pirão que integra diferentes cardápios e amplia as possibilidades de se comer à brasileira. 
A farinha de mandioca está na memória, e na mesa, quando se tem uma receita como a de um cozido, com legumes, carnes frescas e salgadas, embutidos; seu caldo quase que pede para se unir a farinha de mandioca para que assim nascer o tão apreciado "pirão".

Pirão, uma receita bem brasileira, [mas já experimentei no Benim, África ocidental, na cidade de Kotonu, onde fui num restaurante e comi o pirão rouge, ou o pirão vermelho]. O pirão rouge é feito à base de farinha de mandioca, água, sal, e azeite de dendê, o que the confere aquela cor vermelha. Uma verdadeira africanização da receita brasileira, e uma maneira de reinterpretar o dendê, que é uma importante referência das cozinhas locais.

O pirão rouge dentro desse cardápio acompanhava a galinha guisada, uma combinação deliciosa, uma experiência que traz o Brasil e a África juntos, encontro tão nosso, de um povo africanizado e multicultural.

\subsection{A civilização do feijão}

Os feijões são conhecidos em variedade, em diversidade de tipos, e com centenas de nomes populares, e está, sem dúvida, na mesa de grande parcela da população do mundo.

O gênero Phaseolus tem ocorrência em diferentes locais, e por isso é amplamente consumido no Ocidente e no Oriente. Procedente da Índia, Birmânia e Paquistão, o Phaseolus aconitifolius Jac, no início do século XX, foi introduzido nos Estados Unidos, e traz as opções de cardápios com feijão, e juntamente a indústria alimentar oferece as opções de feijões "em lata". Une-se a esse gênero o Phaseolus lantifolius que é nativo dos Estados Unidos.

No Oriente os feijões também constroem hábitos alimentares. Do Japão, o Phaseolus angularis Wild é de uso milenar também na China. Na Índia, o Phaseolus aureus Roxhg tem longa tradição na culinária.

Nas Américas, espécies nativas da América Central, como o Phaseolus lunatus L.; e da America do Sul, como o Phaseolus vulgaris L., formam cardápios dos povos autóctones.

Ainda, o feijão tem outras designações além do clássico Phaseolus, tais como: Vigna unguiculata Walp que é conhecido popularmente como o feijão da China; outro exemplo é o Lablab vulgaris Sabi, também encontrado na Ásia.

Feijões africanos do gênero Phaseolus cajanos, provavelmente do Egito, são introduzidos no Brasil como Lablab Níger; e o Vigna sinensis, o nosso tão popular feijão "frade" ou "fradinho", que procede da África Central.

O feijão é um símbolo da casa, da cozinha, do cotidiano. Uma comida que está na grande maioria das mesas brasileiras.

Então, detalharemos um imaginário que individualiza qual é o tipo de feijão e a sua receita culinária. E assim posso fazer feijão magro; fazer feijão de leite, diga-se, leite de coco; e, destaque para o feijão de azeite, e com essa nominação já se sabe, no caso dos baianos, que o feijão é do tipo fradinho temperado com azeite de dendê.

O feijão de azeite faz parte de um conjunto de partos que integram diferentes cardápios formadas com receitas feitas à base de azeite de dendê, assim como ocorre com a farofa de dendê.

Dessa maneira retoma-se a harmônica dupla feijão e farinha de mandioca. Essa opção de parto é uma das mais gerais, diria até nacionalmente, que encontramos. Diga-se, farinhas de muitos e diferentes tipos, cores, granulaturas e sabores. 
As comidas "de azeite" integram receitas de: carnes, peixes, aves, crustáceos, verduras, ovos; e tudo mais que possa ser celebrado no dendê, que também pode ser chamado de "azeite de cheiro". Além do dendê, a mão africana misturou ainda com o feijão frade com o leite de coco.

O feijão fradinho faz parte de uma rica culinária de receitas à base de dendê, como o emblemático acarajé da nossa cozinha afro-baiana.

Muitos, tantos e saborosos, são os feijões que formam estilos e tendências do "comer à brasileira". São feijões nativos, outros exóticos, e muitos foram tropicalizados, e passaram a fazer parte das nossas melhores receitas.

Pode-se dizer que o brasileiro, em geral, é um comedor de feijão, seja com farinha de mandioca, seja com arroz; e com tudo mais que a invenção puder mostrar através das receitas regionais.

O feijão é um tema cotidiano, que simboliza para milhares de brasileiros um entendimento do ato de comer, que só será completo se tiver feijão.

\subsection{Fazer comida é fazer história}

As mulheres especialistas na elaboração dos alimentos sagrados dos orixás são preparadas dentro do rigor dos cultos, que procuram manter as escolhas dos ingredientes, e as receitas, como importantes elos que podem unir o homem aos seus deuses.

As comidas são partilhadas com os deuses nos seus santuários, também são oferecidas aos que participam dos rituais, das festas, inclusive os visitantes, que na maioria das vezes também tem o desejo de experimentar essa ligação com os orixás, e por isso buscam comer nos terreiros, porque sabe-se que há fartura e variedade de alimentos.

É altamente socializante este ato de compartilhar o mesmo alimento dentro de um grupo. As comidas são servidas ao término das grandes celebrações públicas dos terreiros. Assim, há a união das pessoas que têm os mesmos objetivos religiosos e os mesmos sentimentos de fé, que são reforçados pelo ato de ingerir os alimentos preparados pelas yabás, yabassês, como afirmação de pertencimento.

$\mathrm{Na}$ realidade, é na preparação desses quitutes das mesas dos deuses africanos que constatamos a necessária utilização do dendê, juntamente com as favas e frutos de origem africana, importantes na realização dos alimentos rituais, o que garantirá a sua eficácia e destinação entre a boca e o sagrado.

Acarajé, caruru, amalá, ipeté, bobó, omolocum, erã-peterê, e farofas, são alguns dos alimentos que mostram suas funções religiosas no vasto cardápio votivo dos deuses.

Um caso exemplar é o do acarajé, bolo frito no azeite-de-dendê, em porções determinadas pelo próprio tamanho da colher de pau. A sua massa é feita de feijão-fradinho, pisado no pilão, ou ralado em pedra especial, e os temperos principais são a cebola e o sal.

Exu, Ogum, Oxóssi, lansã, Xangô, Obá, Ewa, Oxumaré, Ibejis, são alguns dos deuses que têm o acarajé como um dos principais alimentos rituais, e que são feitos em formatos especiais e na quantidade para fazer parte dos seus rituais de alimentação sagrada

A ialorixá Eugenia Anna dos Santos, Aninha, do Ilê Axé Opô Afonjá, Salvador, por ocasião do II Congresso Afro-Brasileiro, realizado em 1937, nesta cidade, contribuiu com um comunicado sobre a culinária desenvolvida no seu terreiro. 
Entre os muitos pratos e bebidas, destaca o emún, segundo a informante, bebida africana feita com dendê.

Este vinho é também chamado de malafu ou sura pelos congoleses, e no caso afro-brasileiro ganhou notoriedade como marafo, o que designava não apenas o vinho de dendê, mas também a cachaça feita de cana sacarina, e integrava um elenco de bebidas fortes, e por isto tinha um significado viril, masculino.

Hoje desaparecido dos rituais religiosos dos terreiros de candomblé, e das vendas de rua, o vinho de dendê é apenas uma lembrança. Os Candomblés e Xangôs restringem-se a algumas bebidas de função litúrgica como o aluá, tipo de bebida feita à base de água, milho, rapadura, gengibre.

Ainda, no depoimento da ialorixá Aninha, ela relata as comidas do seu terreiro: abará, abarém, acaçá, acarajé, ado, afurá, amori, aluá, ambrozô, anduzada, anguzô, aponom, arampaterê, arroz-de-haussá, axoxô, badofe, bambá, bobó, caruru, curu, cuxá, denguê, erampeterê, fufu, omolucum, ipeté, latipá, lelê, mungunzá, oguedê, olubó, quibebe, quibombó, quimana, quissamã, quitandê, sabongo, vatapá, xinxim, entre outras.

Para entender e gostar, é preciso comer, mas antes deve-se olhar, identificar; emocionar-se com os ingredientes, as cores, as texturas e os aromas; e depois colocar na boca, e assim sentir um pouco desta África no Brasil. E tudo isso é para se viver de corpo inteiro nesta nossa rica e criativa cozinha afrodescendente, a cozinha de dendê.

\section{DENDÊ E A COMIDA PATRIMONIAL}

Acarajé é uma comida do final da tarde.

É uma comida de lansã, orixá dos ventos e que representa a mulher livre.

lansã, que também é conhecida por Oyá, ensinou a mulher o ofício de fazer acarajé.

É comida de rua, para ser feita na hora.

É uma comida de mercado, de tabuleiro.

(Grifo do autor)

\subsection{Do terreiro ao tabuleiro}

O olhar da Patrimonialização sobre os processos sociais relacionados ao ato de se fazer a comida se dá através do entendimento que cada vez mais a comida deve ser valorizada como uma manifestação cultural, que tanto sensibiliza quanto se comunica com o seu meio ambiente, a sua sociedade, e o seu período histórico.

Além disso, a comida exige que todos os sentidos e sentimentos pessoais estejam, verdadeiramente, integrados, para que o corpo e a memória resgatem ou atribuam um valor simbólico àquela receita ou aquele ingrediente especial.

Certamente é na boca que começa a emoção. Porém, o paladar é apoiado pelos sentidos da visão, olfato, tato e até a audição, para compartilhar este momento de comensalidade, e para que a comida seja, desse modo, integralmente entendida e assimilada dentro do seu espaço cultural.

Comer não é apenas um ato biológico, é antes de tudo um ato simbólico, que através de gestos, de sinais, de reconhecimentos, há um diálogo, pessoal ou coletivo, com aquele alimento que se comunica através de cores, de texturas, de temperaturas e de sua estética. 
O valor cultural do ato de comer é cada vez mais entendido como um ato patrimonial, pois a comida é tradutora de povos, nações, civilizações, grupos étnicos, comunidades, famílias, pessoas. O sentido de pertencer a uma sociedade, a uma cultura, nasce primordialmente no idioma que falamos e na comida que comemos.

Receitas, pratos, hábitos cotidianos, marcam um lugar que define e aufere a pessoa a sua identidade.

A presença da matriz africana está principalmente nas receitas que fundamenta, particulariza, e assim constrói a nossa culinária, que diante do paladar brasileiro, foi marcada com expressão pelo dendê.

A nominação de produtos, ingredientes e temperos, apontam para a diversidade de povos e de civilizações que integram a nossa mesa e os nossos hábitos alimentares.

E, no caso brasileiro, o acarajé foi escolhido para ser um interlocutor privilegiado e patrimonial desta ampla e múltipla relação com o continente africano na formação da mesa brasileira; pois, muitos pratos de matriz africana, o acarajé é um dos mais importantes, pelo que significa em âmbito social e religioso, e pelo que significa na afirmação de uma longa tradição de vender comida na rua, no caso com a baiana de acarajé.

A venda de acarajé no tabuleiro é uma permanência econômica que data da época dos "ganhos". O acarajé está no processo histórico dos povos africanos no Brasil, e marca o Estado da Bahia, e, em especial, a cidade do São Salvador. Há uma profunda identidade do acarajé com o povo baiano nas suas muitas tradições culturais.

O acarajé nasce do feijão fradinho que é processado num pilão de pedra - pilão lítico -, na forma mais tradicional. A massa é acrescida de cebola ralada, sal, e deve ser muito bem batida para manter aeração, e alcançar a qualidade necessária. $O$ acarajé tradicional tem o formato e tamanho de uma colher de sopa. Deve ser comido quente, puro, ou com molho de pimenta; e pode conter ainda vatapá, caruru, salada, e camarão defumado, transformando-se num verdadeiro sanduíche, popularmente chamado de "sanduíche Nagô".

Comer acarajé no final de tarde na cidade do São Salvador é um costume que pontua o cotidiano. É um encontro, e reencontro, diário com a matriz africana. O tabuleiro torna-se uma referência de identidade e de lugar social africano que marca o paladar brasileiro.

$\mathrm{O}$ acarajé é frito na hora. $\mathrm{O}$ aroma do dendê borbulhando atrai os devotados consumidores deste bolinho. Ele pode ser uma refeição ou um lanche.

O acarajé nomina também um dos rituais mais importantes dos terreiros de candomblé, que é chamado de acarajé de lansã, quando no barracão, espaço público, os acarajés são distribuídos a todos os presentes, oferta feita pelos orixás, pessoas em estado-de-santo, lansã ou Oyá.

Estes acarajés estão em gamelas de madeira, em grandes utensílios de cobres, ou em tabuleiros semelhantes aos das vendas de rua, para serem ritualmente distribuídos.

Assim, as comidas de dendê preservam uma comunicação imediata através de ações que mostram o papel social da mulher no oficio de fazer e de vender acarajé.

\subsection{Baiana de acarajé: um ofício reconhecido como patrimônio nacional}

Heroico é esse acarajé que se tornou um símbolo de patrimônio gastronômico que representa história e mitologia. Ele é um patrimônio, tanto quanto o barroco recoberto de ouro das 
igrejas coloniais, os azulejos, a prataria, as alfaias, as louças seculares; a arquitetura, e os monumentos equestres dos heróis oficiais.

São vários os significados que situam a mulher como um agente memorial e provedor das famílias afrodescendentes, e que marcam o seu importante papel social dentro das inúmeras falas culturais, na trajetória civilizadora dos povos e culturas africanas no Brasil.

Democraticamente o conceito de patrimônio cultural ampliou-se diante dos avanços das políticas públicas do Estado. E passa-se a compreender a cultura de maneira plural e contextual, dáse aos seus realizadores, pela experiência e vivência, um valor mais amplo como integrante do segmento cultural que singulariza a sua identidade de povo e de nação. Esta é a compreensão mais atual, e internacional, sobre patrimônio cultural.

É justamente no que há de particular, próprio e diferente, que se marca uma identidade.

E por tudo isso, o acarajé, comida tradicional que compõe o cardápio do tabuleiro da baiana, marca o "Ofício da Baiana de Acarajé", e faz com que este ofício seja registrado em dezembro de 2004, como “Patrimônio Cultural Imaterial Brasileiro" pelo IPHAN - Instituto do Patrimônio Histórico e Arquitetônico Nacional.

O reconhecimento patrimonial da comida e, em destaque, dos seus processos de produção, é um reconhecimento do quanto é importante para os sistemas alimentares a preservação do conhecimento de uma receita e o seu processo culinário na formação da identidade, e na afirmação dos direitos culturais, pois só assim há o fortalecimento da cidadania.

As experiências durante o processo de Patrimonialização do ofício da baiana de acarajé, que teve a interlocução privilegiada a ABAM - Associação das Baianas de Acarajé e Mingau -, possibilitou um mergulho nas relações inter-baianas de acarajé, dentro do seu universo da venda, das necessidades dos processos culinários, da manutenção de um cardápio, da necessidade do seu traje completo, de marcar o seu espaço físico na cidade, e, em especial, o seu lugar social, e demais temas que mostram toda a complexidade da chamada venda, ou do tabuleiro da baiana de acarajé.

\subsection{O Processo de Patrimonialização}

A partir da minha experiência na coordenação das pesquisas de campo para a Patrimonialização do "Ofício das Baianas de Acarajé" pelo IPHAN, para o registro como Patrimônio Imaterial do Brasil, trago o relato deste trabalho pioneiro no âmbito da Patrimonialização de temas referentes às comidas e, em especial, sobre os saberes tradicionais em diferentes contextos sociais e culturais.

Eu participei do processo de Patrimonialização do "Ofício da baiana de Acarajé", e inicialmente quis traduzir dentro da minha interlocução com as representantes da ABAM como seria realizada esta Patrimonialização do ofício, como seria as suas características metodologias, e o que este reconhecimento patrimonial por parte do Estado, o "Registro", traria de benefícios para esta classe trabalhadora.

As conversas foram longas e muitas, e para mostrar a importância da Patrimonialização como um recurso para as reinvindicações da classe, mostrei uma base para o entendimento de que o registro além de um valor social tem um valor político.

E assim, foi organizado uma exposição de temas para serem discutidos com as profissionais do acarajé, e, desse modo, iniciar uma ação de educação patrimonial, que reforçaria a sua compreensão própria enquanto mulher que detentora de um saber de importância nacional. 
Foi ainda preparado um material didático para que houvesse um melhor entendimento de que o patrimônio, nesta sua vertente de "patrimônio imaterial", e como ele valoriza as muitas manifestações das culturas, e das diferentes matrizes étnicas, e que no caso do Brasil havia a ênfase na matriz africana.

A primeira ação prática feita foi mostrar que o tombamento, termo mais conhecido e usual em virtude do longa processo de experiencia de reconhecimento da cultura material, de pedra e cal, especialmente na arquitetura, e em outros monumentos, vem para proteger os testemunhos que traduzem simbolicamente classes sociais, que no caso do patrimônio material foi na sua maioria das classes dominantes.

Ainda nesta metodologia expositiva sobre o que era tombamento, que vigora um caráter de retenção memorial, e de que o tombo torna imexível aquilo que é tombado.

A partir do momento que essa compreensão entrou dentro do mundo-visão das baianas de acarajé, segui para o meu objetivo de traduzir toda a amplitude e o sentido democrático que faz parte das bases conceituais do patrimônio imaterial.

Assim, dialoguei sobre os atuais cenários sociais, e como poderia ser feita a promoção dos direitos culturais e da cidadania. E como uma receita, os seus processos culinários, os seus rituais sociais dentro da alimentação, entre tantos, faziam parte de um importante acervo de temas que são valorizados pelo patrimônio imaterial.

\subsection{A estética da comida unida a estética da roupa: um olhar etnográfico para a roupa de baiana, o seu ofício e o seu tabuleiro}

Roupa de baiana, roupa de crioula; estar de saia, mulher de saia; baiana de passeio, baiana de candomblé; baiana do Bonfim, baiana da Boa Morte; beca ou simplesmente baiana; são as denominações dadas ao traje de matriz africana que aponta e reúne os elementos visuais do barroco europeu.

Esta roupa traz tecnologias, cores, texturas, volumes; peças africanas do Ocidente; elemento que marcam a forte presença afro-islâmica, diretamente das relações entre o Islã e a África. Ainda, traz a península Ibérica, com as relações de portugueses e espanhóis com os mesmos povos do Islã, os mouros, os muçulmanos, e tudo isso formou um tipo consagrado como "roupa de baiana".

É uma roupa que identifica os múltiplos papéis sociais da mulher, e a sua vinculação às diferentes manifestações de matriz africana, entre elas o ofício de fazer e vender acarajé na rua, no "tabuleiro".

A primeira e marcante identificação da "roupa de baiana", que se dá pela cabeça coberta, com tecido de diferentes formatos e texturas, conforme intenção social, religiosa, e étnica, é o turbante. E o nosso turbante afrodescendente é, sem dúvida, afro-islâmico.

A saia é outro elemento marcante da roupa. A saia é geralmente feita com cinco ou sete metros de roda, e com tecidos diversos, fitas, rendas, entre demais detalhes na barra.

Há o "camizu", que é geralmente rebordado na altura do busto, e uma bata por cima, feita com tecido mais fino.

O "pano de Costa" - pano de Alaká - é um tipo de distintivo que tem diferentes usos. Este pano africano pode ser tecido em tear manual, ou ser industrial.

Assim, a roupa de baiana, "estar de saia" ou "usar saia", refere-se a um elaboradíssimo conjunto que monta este traje tradicional que identifica a baiana. 
Os objetos simbólicos feitos em diferentes materiais, como, por exemplo, os balangandãs, unem-se a estética da roupa de baiana. E alguns balangandãs estão visíveis nas pencas, e têm origens e funções específicas dentro da atividade econômica da venda de rua.

O balangandã pode ter: bolas de louças, figas, saquinhos de couro; dentes de animais, medalhinhas, crucifixos; símbolos cristãos que foram absorvidos e relidos pela matriz africana. Hoje, estão ausentes na composição da roupa de baiana.

Atualmente, há outros elementos visuais que compõem a roupa de baiana como, por exemplo, os fios-de-conta e as pulseiras, o que mantêm simbolicamente as marcas sociais e religiosas.

Essa joalheria que compõe a roupa de baiana traz também brincos, do tipo pitanga ou do tipo barrilzinho; ides - pulseiras de búzio, de contas, de corais, de marfim, de prata, de ouro, de cobre, de latão, de ferro; colares do tipo "trancelim", ou com argolas encadeadas; e os "ilequês", com as cores simbólicas dos deuses pessoais, da família ou da nação e terreiro.

A roupa de baiana compõe e fundamenta o imaginário do ofício de fazer e vender acarajé, e as demais comidas que integram o cardápio do tabuleiro.

Ainda, dentro da compreensão ampla da venda dos acarajés, além da roupa, há o oferecimento ritual do acarajé que é feito em tamanhos menores do que uma colher de sopa, que são fritos e oferecidos, para depois se iniciar a venda das comidas nos tabuleiros.

Estes acarajés têm a função de realizar o ritual de despachar a rua; ainda o local poderá ser lavado com água para ser purificado, que é preparada com maceração folhas, entre outros rituais que buscam a boa venda das comidas.

As comidas nos tabuleiros são apresentadas de forma suntuosa, e trazem também um caráter barroco, tudo acontece no cenário estético para aguçar o sabor e o desejo.

\section{CONCLUSÃO}

O interlocutor deste processo tão complexo e intenso é a palmeira do dendezeiro, realizado pelo azeite de dendê, um ingrediente fundamental na construção das identidades regionais das nossas cozinhas, e na formação de um rico e diverso acervo culinário de matriz africana no Brasil.

Assim, neste entendimento plural sobre comida e cultura, o azeite dendê mostrou-se amplamente nos espaços sagrados, nas festas, no cotidiano, também no sentido memorial, social, e forte elemento que pode ser usado como indicador para estudos da antropologia da alimentação.

Em contexto contemporâneo, as comidas e seus processos e significados ganham destaque no entendimento dos patrimônios imateriais, que cada vez mais buscam recuperar memórias, para preservar os saberes e os lugares como representações singulares da nossa cultura.

Estas pesquisas etnográficas in loco fazem parte das minhas bases de conteúdos para as minhas interpretações antropológicas, e estão aliadas aos livros e artigos que li, e que fiz dedicados ao dendê dentro dos variados cenários da alimentação brasileira.

\section{REFERÊNCIAS}

BASCON, W. Ifá divination. Londres: Indiana University Press, 1969.

BEIR, U. Yorubá myths. Cambridge: Cambridge University Press, 1980. 
CARNEIRO, E. Ladinos e crioulos. Rio de Janeiro: Civilização Brasileira, 1964.

CASCUDO, L. C. História da alimentação no Brasil. Belo Horizonte: Itatiaia; São Paulo: Edusp, 1983.

LODY, R. O dendê e a comida de santo. Recife: Instituto Joaquim Nabuco de Pesquisas Sociais, Centro de Estudos Folclóricos, 1977. (Folclore; 43).

LODY, R. Espaço, orixá, sociedade: um ensaio de antropologia visual. Rio de Janeiro: Ed. Do Autor, 1984.

LODY, R. Samba de caboclo. Rio de Janeiro: CDFB, 1977.

LODY, R. Artesanato religioso afro-brasileiro. Rio de Janeiro: IBAM, 1980.

LODY, R. Santo também come. Prefácio de Gilberto Freyre. Rio de janeiro: Artenova; Recife: Instituto Joaquim Nabuco de Pesquisas Sociais, 1979.

LODY, R. Tem dendê, tem axé: etnografia do dendezeiro. Rio de Janeiro: Pallas, 1993. 120 p.

LODY, R. Cozinha Plural. In: A culinária baiana no Restaurante do SENAC Pelourinho. Rio de Janeiro: Salamandra. 130 p. Edição português e inglês e Edição português e francês, 1996.

LODY, R. O rei come quiabo e a rainha come fogo. In: Leopardo dos olhos de fogo. São Paulo: Ateliê Editorial, 1998.

LODY, R. Cozinha brasileira: uma aventura de 500 anos. In: Formação da culinária brasileira. Rio de Janeiro: Sistema CNC, SESC, SENAC, 2000.

LODY, R. Presencia de África em la gastronomia de Bahia. In: Patrimônio Cultural y Turismo. Congresso sobre Patrimônio Gastronômico y Turismo Cultural em América Latina y el Caribe. Memórias. Tomo II. México: Conaculta. Tomos I, II, III. Cuadernos, 2002.

LODY, R. Axé do acarajé: argumento, pesquisa e roteiro. Documentário 52 m., direção Polla Ribeiro. Fundação Palmares, CNCP/IPHAN, 2006.

LODY, R. Museu da Gastronomia Baiana (catálogo). Salvador: Senac Bahia. Edição Português/Inglês/Espanhol, 2007. $48 p$.

LODY, R. Brasil Bom de Boca. Temas da antropologia da alimentação. Editora Senac: São Paulo, 2008. 424p.

LODY, R. Acarajé. Comida y Patrimonio Del Pueblo Brasileño. La patrimonialización Del acarajé in Identidades em Plato. El patrimônio cultural alimentario entre Europa y America. Icaria, Observatorio de la Alimentación, Barcelona, 2008.

LODY, R. Dendê: bom de comer, de ver e de significar a matriz africana no Brasil. In: Dendê. Símbolo e sabor da Bahia (organizador). São Paulo: Editora Senac São Paulo, 2009. 147p.

LODY, R. (Org). Dicionário do Doceiro Brasileiro. (Dr. Antonio José de Souza Rego, 1892). Organização da obra (Introdução: Doce Comida; análise de receitas e glossário). São Paulo: Editora Senac São Paulo, 2010. 325 p.

LODY, R. Coco. Comida, cultura e patrimônio. São Paulo: Editora Senac São Paulo, 2011. 196p.

LODY, R. Vocabulário do Açúcar. Histórias, cultura, e gastronomia da cana sacarina no Brasil. São Paulo: Editora Senac São Paulo, 2011. 197p.

LODY, R. Caminhos do Açúcar. Ecologia, gastronomia, moda, religiosidade e roteiros turísticos a partir de Gilberto Freyre. Rio de Janeiro: Topbooks Editora, 2011. 305p.

LODY, R. Bahia boa de comer: do carimã ao dendê. In: A Mesa com Carybé. (Organizador) Rio de janeiro: Senac Nacional, 2007. 118p. 
LODY, R. A roupa de baiana. Salvador: Memorial das Baianas de Acarajé, 2003. 28p.

LODY, R. Bahia bem temperada. Cultura gastronômica e receitas tradicionais. São Paulo: Editora Senac São Paulo, 2013. 153p.

MAIA, S. A. Dicionário complementar português-Kimbundu-Kikongo. Luanda: Tip. Das Missões Cucujães, 1961.

PEIXOTO, A. Breviário da Bahia. Rio de Janeiro: Conselho Federal de Cultura, 1980.

SANTOS, J. E. Os nagôs e a morte. Petrópolis: Vozes, 1976.

SANTOS, E. A. Nota sobre comestíveis africanos. In: O negro no Brasil. Rio de Janeiro: Civilização Brasileira, 1940. 